\title{
Effective Commuity Response to Disaster: A Community Approach to Disaster Preparedness and Response ${ }^{1}$
}

\section{M.A. Brennan²}

This paper is part of a series of discussions on the impact of community action in response to natural and other disasters.

\section{Introduction}

The dramatic and tragic events of Hurricane Katrina and the 2005 hurricane season have highlighted the need for coordinated community based volunteer efforts to prepare for, and respond to, natural and other disasters. The recent disasters in the Gulf States underscores the problems and shortcomings associated with coordinating outside logistics and show a clear need for local volunteers to serve as the first line of response to such catastrophes. For example, this was most obvious in the first weeks after Hurricane Katrina, where volunteers and active community residents were the rescuers, caretakers, and in many cases, the final comforting companions to the dying. They were the first, and often the only, line of response that would exist for weeks. Government officials have immediately called on local citizens to volunteer their time, money, and sweat equity in addressing these massive and unprecedented natural disasters.
Such disasters are likely to occur again. The routine threats from hurricanes, tornados, flooding, and other natural disasters to the southeastern US and elsewhere are well documented and predicted. In particular, given the trend of increased storm intensity, the likelihood of the impending threat of severe hurricanes (Category 4 or 5) requires careful crisis and emergency planning strategies. Similarly, the possibility of terrorism remains an ever present threat.

When disasters do occur, citizen groups and coordinated efforts of local volunteers can respond to lessen the impacts and "build back better." Local residents will be the first responders. However, the process of organizing local residents must take place before, during, and after such catastrophic events occur (Berke et al., 1993). This factsheet identifies and suggests methods for linking local organizations, recruiting volunteers, and implementing coordinated action plans prior to, and after, the impact of natural disasters.

1. This document is FCS9254, one of a series of the Family Youth and Community Sciences Department, Florida Cooperative Extension Service, Institute of Food and Agricultural Sciences, University of Florida. Original publication date July 25, 2006. Visit the EDIS Web Site at http://edis.ifas.ufl.edu.

2. M. A. Brennan, assistant professor, Department of Family, Youth and Community Sciences, Cooperative Extension Service, Institute of Food and Agricultural Sciences, University of Florida, Gainesville, FL, 32611

The Institute of Food and Agricultural Sciences (IFAS) is an Equal Opportunity Institution authorized to provide research, educational information and other services only to individuals and institutions that function with non-discrimination with respect to race, creed, color, religion, age, disability, sex, sexual orientation, marital status, national origin, political opinions or affiliations. U.S. Department of Agriculture, Cooperative Extension Service, University of Florida, IFAS, Florida A. \& M. University Cooperative Extension Program, and Boards of County Commissioners Cooperating. Larry Arrington, Dean 


\section{Importance and Role of Community in Disaster Preparation and Recovery}

In recent years considerably more emphasis has been placed on the role of community in disaster recovery and on the importance of local knowledge, action, participation, and control in determining the nature of disaster response.

It is logical that the community should be the first line of defense in preparing and responding in the event of disaster. Local residents and groups are in a position to best identify their immediate needs, coordinate preparations, supplement official response efforts, implement emergency response programs, and contribute to local decision making for future events. Similarly, local communities can provide a sense of connection, and decrease the isolation and abandonment that is often felt among residents in times of disaster. Such capacity for providing these community services does not always exist, but can be cultivated and should be encouraged and empowered.

In all communities, a variety of groups exist with diverse skills and abilities combined with personal and professional experiences that are essential to successful preparation and response to disasters (Independent Sector, 2001). Included are resident groups with needed professional and trade skills for damage control and assessment (engineers, environmental scientists, architects, contractors, and skilled laborers); disaster preparedness and response training (VFW, retired military/national guard/police); medical, psychological and social service delivery experience (health practitioners, counselors, religious/civic groups); and long time residents who have witnessed previous responses to natural disasters.

Effective community responses connect these diverse groups and develop action plans to meet common needs. Successfully linking local organizations, citizens, and leaders provides a strong network for local citizens and groups to become actively involved in local preparedness and response efforts. To be most effective, this process of capacity building must take place before disasters occur, and continue during and after such catastrophic events. Extension and other change agents can help facilitate this process.

\section{The Role of Extension in Community Responses to Disaster}

To facilitate such citizen involvement, training at a variety of levels is useful. First, community development/civic engagement training should be the cornerstone of all community based disaster response programs. Such trainings provided by Extension and other community development educators would provide an understanding and framework for including broad based local representation into long-term emergency response and other local efforts. These trainings should include skill development such as asset mapping, assessing local power structures, needs assessments, conflict resolution skills, management methods, and community profile development. Such training would also inform active citizens that their involvement is essential to local development well beyond times of disaster.

Similarly, more general grassroots mobilizations can plan for, respond to, and rebuild in the aftermath of disaster. Included would be active efforts to bring together diverse local groups, the formation of local groups for planning, establishment of formal long-term visioning and goal setting for disaster preparation/recovery, and recruitment of experienced local citizens to take direct action. Similarly, the establishment of alliances between local groups could set the stage for a more effective sharing of resources and responsibilities during times of crisis. Such alliances can include the identification of organizations or individuals to serve as liaisons between local grassroots efforts and more formal structures (state and federal response organizations, military/national guard, emergence response agencies). Extension programming and trainings can be a valuable resource in facilitating all of these activities and skills. 


\section{Ways Community Volunteers Can Help}

An organized community and volunteer response can help in a number of ways before, during, and immediately after the recent disasters. They are able to:

- coordinate a more successful evacuation and transportation effort;

- provide some structure and order instead of chaos;

- aide in organizing resources for distribution before and after disasters;

- decrease the isolation and sense of abandonment that quickly engulfs disaster victims in the affected areas; and

- contribute to local connections and interaction that signals the development of community.

\section{Conclusion}

Local volunteers and community level action is essential to effective natural disaster preparation and response. They are particularly important because citizens are in many cases the first responders and have the greatest chance to save lives and provide support in the hours and days immediately after disaster occurrences. Certainly, an effective community response would have diminished some of the suffering and loss that occurred during and after the recent disasters.

Community and volunteer coordinators have an obligation to help facilitate community organization and preparation to aid fellow citizens it times of such great need. The only thing that is certain in these times is that local residents will be the first people capable of responding. In these disaster settings, local volunteers and community organizations are presented with an unprecedented opportunity to make a measurable impact on local well-being. The quality and extent of this response may hold the key to minimizing disaster effects, maintaining order, increasing hope, and maximizing recovery efforts.
In the end, facilitating local involvement in disaster preparedness and response is about far more than the provision of basic and logistical needs. It ensures that local voices are heard, local struggles are recognized, and the dignity of local people is respected. With this capacity established, local citizens can respond and recover in a manner that improves local life. The response and rebuilding process will belong to the front line of disaster responders — community volunteers_—who will reinvest in their communities.

\section{References and Suggested Reading}

Berke, P. R., J. Kartez, and D. Wenger. 1993. Recovery after Disaster: Achieving Sustainable Development, Mitigation and Equity. Disasters 17(2):93-109.

Flint, C. and M.A. Brennan. 2006. The Rural Context of Disaster: Exploring the Role of Community Emergency Response Teams. Rural Realities.

Brennan, M.A., C. Flint, and R. Barnett. 2005.Community Volunteers: The Front Line of Disaster Response.Journal of Volunteer Administration. 23(4): 52-56.

\section{Useful Web Sites}

1. US Citizen Corps, http://www.citizencorps.gov/

2. Community Emergency Response Team (CERT), http://www.citizencorps.gov/programs/cert.shtm

3. National Citizen Corps Council Partners, http://www.citizencorps.gov/programs/ partners.shtm

4. Corporation for National and Community Service, http://www.cns.gov/

5. US Citizen Fire Corps, http://www.firecorps.org/

6. US On Watch Neighborhood Watch Program, http://www.usaonwatch.org/

7. Medical Reserves Corps, http://www.medicalreservecorps.gov 
8. Volunteers in Police Service, http://www.policevolunteers.org/

9. Citizen Corps Affiliate Programs and Organizations, http://www.citizencorps.gov/programs/ affiliate.shtm 